\title{
Use of Cultivated and Harvested Edible Plants by Caiçaras - What Can Ethnobotany Add to Food Security Discussions?
}

\author{
Mariana Giraldi ${ }^{1}$ \\ Federal University of Santa Catarina, Brazil \\ Natalia Hanazaki \\ Federal University of Santa Catarina, Brazil
}

\section{Abstract}

Human populations along the Brazilian coast have undergone transformations in their livelihoods and recent changes have affected local food security. Caiçaras, traditional inhabitants of the coastal Atlantic Forest, have experienced processes of urbanization, intensification of tourism, and nature conservation, which have influenced their relationships with biodiversity. Within this context, the objective of this research was to analyze livelihoods and food security of the Caiçaras based on a case study in southeastern Brazil, emphasizing the use of food plants that are cultivated and harvested within protected areas. Using an integrative approach of human ecology and ethnobotany, methods included free listing, 24-hour recall, and food storage analysis. The results indicate that food security requires a complementarity between food-and income-generating activities in the studied communities. From all food items consumed by the families interviewed, 8 to 12 percent were local plants; specifically, fruits and spices available in homegardens.

Keywords: Atlantic Forest, diet, human ecology, livelihoods, protected areas

\section{Introduction}

Historically, humans have established social and environmental relationships in order to conduct their ways of life. Such relationships have undergone changes, in part influenced by natural phenomena, as well as by human actions (Mahdi et al., 2009; Ramakrishnan, 2001). According to Ramakrishnan (2001), livelihoods in recent decades have been marked by intensified environmental impacts, such as pollution, ecosystem degradation, and loss of biodiversity. In certain

1 Corresponding author: mariana_giraldi13@yahoo.com.br. 
situations, the combination of these impacts, including political, economic, and cultural aspects, have led to extreme poverty and food insecurity (DFID, 1999; FAO, 2009; Hesselberg \& Yaro, 2006).

Food security is defined as the access to secure, constant, and sufficient food for ingestion in the human diet (Maxwell \& Smith, 1992). Proper nutrition is a human right and when this is not attained, the situation is marked by malnutrition and hunger (CONSEA, 2009). On a global scale, one billion individuals endured the margins of food security in 2009, primarily in developing countries (FAO, 2009). In the same year, around 30 percent of Brazilian households demonstrated some degree of food insecurity, with a higher proportion in rural areas (IBGE, 2010).

Due to its importance in ethical and economic terms, the issue of food security has been a recurrent discussion in many nations and part of political agreements (CONSEA, 2009; MDG, 2010; ONU, 2012). However, despite the efforts to guarantee food security for the future, FAO (2009) predicts difficulties that humans will experience by 2050. For example, production of food plant resources will be affected by climate change and availability of arable land, and water for irrigation will be scarce. In addition, there is the issue of deforestation and biodiversity loss (Ramakrishnan, 2001). Given this situation, FAO (2009) and the National Policy on Food and Nutritional Security in Brazil (CONSEA, 2009) recommend the intensification of family farming as a way to enhance local food sovereignty. Thus, the production of food plants in households (in small homegardens and crop fields), coupled with the harvesting of plants in forest remnants, is extremely important for food security (Kinupp \& Barros, 2010; Pimentel et al., 1997; Valadão et al., 2006).

The investigation of livelihoods, including subsistence activities and eating patterns, helps to clarify risks, benefits, and trends for food security. In Brazil, investigations aimed at understanding the relationships between human populations and natural resources they use have been conducted, for example, along the southeastern coast. Caiçaras, mixed descendants of Amerindians, Europeans, and Africans, are among the inhabitants of this region, and are historically characterized by the practices of fishing activities, small-scale farming, hunting, and extraction of plant resources in the Atlantic Forest (Diegues, 2002). Recently, the southeastern coast has been undergoing an intense process of urbanization and intensification of tourism, contrasting with nature conservation policies. Together, these factors have led local people to increase their participation in commerce-related activities and even to migrate to urban centers (Adams, 2000). Reflecting on this scenario, new relationships have been established between the Caiçaras and natural resources, involving changes in food acquisition and eating habits (Hanazaki \& Begossi, 2000, 2003; Hanazaki et al., 2009, 2013, 2007; MacCord \& Begossi, 2006). 
In the field of ethnobotany, Borges and Peixoto (2009), Cavechia et al. (2014), Hanazaki et al. (2000), Miranda and Hanazaki (2008), Peroni et al. (2008), and Rossato et al. (1999) have investigated the relationships between Caiçaras and plants. With the exception of Cavechia et al. (2014) and Peroni et al. (2008), who studied agrobiodiversity, other research consisted of general ethnobotanical surveys characterized by recording the richness of known and used plants, usually considering the categories medicinal, food, manufacturing, and ornamental. There is minimal research focused on the relationships between Caiçaras and their cultivated and harvested edible plants.

In identifying this gap, our study aimed to analyze livelihoods and food security in two Caiçara communities of Paraty, state of Rio de Janeiro, with a focus on the acquisition and consumption of local plants. We analyzed subsistence activities that generate food and money, and the richness of food plants cultivated and harvested, as well as the habitats where they were obtained. Furthermore, we verified the proportion of local plant resources within families' diets, contrasting the diet composition between summer and winter.

\section{Methods}

\section{Study area}

The municipality of Paraty, located on the coast of Rio de Janeiro, southeastern Brazil, has an area of 925 square kilometers and a population of 37,533, of which 26 percent lives in rural areas (IBGE, 2011). Founded in the mid-sixteenth century, Paraty was characterized by fishing activities and small-scale agriculture, but the past three decades have been marked by tourism and urban development (Adams, 2000; Diegues, 2002). In addition to the urban areas, the city has five protected areas in its territory (Mosaico Bocaina, 2011). Such strategies have contributed to the protection of biological diversity in fragments of the Atlantic Forest, a heavily exploited biome whose remnants represent between 7.91 percent (SOS Mata Atlântica, 2009) and 16 percent (Ribeiro et al., 2009) of the original cover. The establishment of protected areas brought restrictions to land use and occupation by Caiçaras residing within them, who partly depend on natural resources for subsistence. Among the Caiçara communities that fall into this situation are Ponta Negra and Araújo Island, which are the focus of this study.

Ponta Negra $\left(23^{\circ} 20^{\prime} 50^{\prime \prime} \mathrm{S}\right.$ and $\left.44^{\circ} 36^{\prime} 25^{\prime \prime} \mathrm{W}\right)$ is located within two juxtaposed protected areas: the Environmental Protection Area of Cairuçu (Decree No. 89.242 of December 27, 1983) ${ }^{2}$ and Juatinga Ecological Reserve (State Law No.

2 Decreto no. 89.242, de 27 de dezembro de 1983. Retrieved from http://www.icmbio.gov.br/brasil/RJ/areade-protecao-ambiental-de-cairucu/downloads/decreto-no-89-242-de-27-de-dezembro-de-1983. 
1859 of October 1,1991$).^{3}$ The latter is more restrictive and its categorization in the Brazilian system of protected areas is currently under discussion. Access to the village is possible by land and sea. The distance from the center of Paraty to the neighborhood of Laranjeiras is 35 kilometers by road, from where one can take trails through the woods (2-3 hour walk) or small motorboats (20-30 minutes) towards Ponta Negra. Sea transport costs about US\$8 (about R \$15 in April 2012) per trip. Ponta Negra inhabitants and visitors must embark through a private condominium located between the street and the seafront, which implies some restrictions. The community consists of approximately 48 households, and families generally buy food in the center of Paraty on a monthly basis. At the same time they complement their diet with local resources. Ponta Negra is in the midst of very dense vegetation, with some crop fields and functioning cassava flour mills. There is no public lighting system, sewage system, or water treatment.

Araújo Island $\left(23^{\circ} 09^{\prime} 38^{\prime \prime} \mathrm{S}\right.$ and $\left.44^{\circ} 41^{\prime} 41^{\prime \prime} \mathrm{W}\right)$ is also located within the Cairuçu Environmental Protection Area; however, vegetation density and the presence of crop fields are less prominent than in Ponta Negra. It is 11 kilometers by road from the center of Paraty to the community of Praia Grande, from which one must travel by boat to the island (5-10 minutes). The cost of the shuttle is about US $\$ 0.8$ per trip, favoring daily transportation. The community consists of about 118 households, with no sewage system or water treatment. Unlike Ponta Negra, Araújo Island has public lighting and a small market, which facilitates the purchase and storage of food.

Both communities have elementary schools from 1st to 4th grades, community association groups, and government healthcare services.

The choice of Paraty as a study site was due to its inclusion in the project "Community-based resource management and food security in coastal Brazil," a research partnership between universities in Brazil and Canada. The project proposal, under a human ecology focus, was to investigate changes in livelihoods in coastal southeastern Brazil and discuss the Caiçara food security. Contributing to this theme, and from an ethnobotanical perspective, we selected the two communities based on the following criteria: difficult access to the urban center of Paraty; a high number of fishermen in the community; and representativeness of edible plants in crop fields, woodlands, and homegardens (this latter based on Hanazaki et al. 2013).

3 Lei Estadual no. 1859, de $1^{\circ}$ de outubro de 1991. Retrieved from http://www.jusbrasil.com.br/ legislacao/151227/lei-1859-91-rio-de-janeiro-rj. 


\section{Data collection}

Due to the fact that this research ${ }^{4}$ was included within a larger project, some steps were completed in collaboration with other researchers. In January 2010 a diagnostic trip was made to Paraty and in June-July 2010 a collective effort was made to obtain socioeconomic data from participating communities (see Hanazaki et al., 2013). The number of households visited followed a sampling error of 10 percent of the total number of households estimated (Barbetta, 2002). The sampling was probabilistic, in which homes were visited by areas, aimed at a more heterogeneous sample (Albuquerque, Lucena, \& Alencar, 2010; Dufour \& Teufel, 1995). The Laboratory of Human Ecology and Ethnobotany at the Federal University of Santa Catarina made available socioeconomic information for Ponta Negra and Araújo Island.

We used semi-structured interviews to collect ethnobotanical data, including free listing, 24-hour recall, and food storage analysis, (Albuquerque, Lucena, \& Neto, 2010; Dufour \& Teufel, 1995), and to obtain additional socioeconomic information about family income and food expenditure in the month prior to the visit. Following Murrieta et al. (1999), family unit was seen as the spatial domain of the residence and its current occupants. It is worth noting that, whenever possible, informants were the chief or head of the household, also allowing the participation of other household members.

The informants were asked to free list local names of known edible plants, and then to indicate which of them were consumed in the residence during the past year. Furthermore, respondents indicated the sites where plants mentioned were obtained. Food consumed in the last 24 hours by members of the family unit was accessed through the 24-hour recall method. Food storage analysis allowed for the recording of food present in the residence at the time of the visits. The 24-hour recall and food storage analysis were conducted in February and July 2011 to verify and compare diet composition. Questions related to income and monthly expenditure on food were also repeated. February represented summer, which is the high season for tourism and intense fishing activity. July represented winter, which is a low season for tourism and little fishing activity (Hanazaki \& Begossi, 2000).

Plants recorded in the free lists were photographed and collected during guided tours with key informants in crop fields, homegardens, trails, and woodlands (Albuquerque, Lucena, \& Neto, 2010). We identified the cited plants in situ

\footnotetext{
4 This study was approved by the Brazilian National Ethics Committee for Research (authorization FR-391341). Free and informed consent was obtained with all visited households, according to Resolution CNS 196/96 (Brasil, 2002). Additionally, since both communities are inside a federal protected area, the collection and transfer of plant materials were authorized by the Chico Mendes Institute for Biodiversity Conservation (authorization number 26930-1).
} 
and ex situ with the aid of botanical literature (Lorenzi, 2010; Lorenzi et al., 2006; Reis, 2006) and consulting specialists. The taxonomy followed the APG II system (Lorenzi \& Souza, 2008) and scientific nomenclature was verified by querying the TROPICOS online database. ${ }^{5}$ Herbarium specimens were incorporated into the Dárdano de Andrade Lima Herbarium at the Agronomic Institute of Pernambuco (vouchers 86608 to 86618), and into the Vasconcelos Sobrinho Herbarium at the Federal Rural University of Pernambuco (vouchers 50914 to 50925).

\section{Data analysis}

Heterogeneity of the sample according to different socioeconomic profiles was verified through a cluster analysis by unweighted pair group method with arithmetic mean using simple matching similarity coefficient (Valentin, 2000) and the software MVSP 3.1 (Kovach, 2005). We used the following variables (obtained from the socioeconomic databases): number of individuals per household, presence of fishermen and/or farmers in the household, food shortages in the past year, and perceptions of diet quality and quality of life (details in Hanazaki et al., 2013).

Activities related to food and income generation were recorded for frequency of citations, per family and per individual, respectively. Data on the number of persons per household, age group, monthly income, and amount spent on food were analyzed by descriptive statistics, taking average values for normal samples and the median for non-normal samples (Vieira, 1991). Normality ( $p$ $>0.05$ ) was verified through the Shapiro-Wilk and Lilliefors tests, using the software BioEstat 5.0 (Ayres et al., 2007).

Food plants mentioned in the free lists were analyzed for richness (Peroni et al., 2010), where the local names, in a proposed emic classification, considered responses at the folk generic (e.g., banana) and the folk specific (e.g., bananaprata) levels (Mourão \& Montenegro, 2006). Descriptive statistics were also used to determine the most-cited plants. Initially, local names were tabulated per community, separately considering categories of "knowledge" and "use in the past year." For the samples that did not have a normal distribution of citations the median was used as a central point (Vieira, 1991). Food plants were considered the most frequent when they were located above the third quartile (representing the 25 percent most cited in both categories and in both communities). For sites where plants mentioned were obtained, analysis was done considering the frequency of the habitat indicated by informants.

5 http://www.tropicos.org/. 
From the 24-hour recall information it was possible to account for the contribution of edible plants in the Caiçara diet, as well as the frequency of citations. In addition, the proportion of "fruits," "spices," "roots and tubers," "vegetables" and "others" in the diet of the families studied was verified. The group "others" included stems, seeds, and palm hearts.

A chi-square test $\left(X^{2}\right)$ was done using the software BioEstat 5.0 (Ayres et al., 2007 ) in order to identify significant differences ( $p \leq 0.05)$ (Albuquerque, Medeiros, \& Almeida, 2010) in diet composition between summer and winter. To evaluate these differences only households visited in both seasons were considered. Researchers grouped food items registered in the 24-hour recall and food storage analysis into "purchased food," "local food of animal origin," and "local food of plant origin."

\section{Results}

We visited 21 homes in Ponta Negra and 43 in Araújo Island in February and revisited 16 and 40 homes in July, respectively. This research could not be conducted for all intended households due to six refusals, seven families absent at the time of visits, and four canceled interviews. The sample comprised two socioeconomic profiles in each community (groups A, B, C, and D) (Table 1), indicating the existence of distinct intrapopulation profiles.

Table 1. Study design and stratification of the samples in Ponta Negra and Araújo Island, Paraty, Brazil

\begin{tabular}{|c|c|c|c|c|}
\hline Community & \multicolumn{2}{|c|}{ Ponta Negra } & \multicolumn{2}{|c|}{ Araújo Island } \\
\hline Estimated number of family units in the community & \multicolumn{2}{|c|}{48} & \multicolumn{2}{|c|}{118} \\
\hline Number of family units in the databases & \multicolumn{2}{|c|}{$32 *$} & \multicolumn{2}{|c|}{$54 * *$} \\
\hline Sample stratification & A & B & C & $\mathrm{D}$ \\
\hline Number of family units visited per grouping & 7 & 14 & 11 & 32 \\
\hline Number of family units revisited per grouping & 4 & 12 & 11 & 29 \\
\hline
\end{tabular}

\footnotetext{
* Three interviews were excluded because they represented the same family unit.
}

** One interview was excluded at the request of the informant.

The population sampled in Ponta Negra corresponded to 94 individuals (43 females and 51 males) in 21 households. The age of subjects $(n=90)$ ranged from 6 months to 77 years old, with the median from age 9 to 39 years. Each household had on average 4.5 people, ranging from 1 to 10 . Median monthly household income was US\$319 in the summer $(n=19)$ and US\$387 in the winter $(\mathrm{n}=12)$. Median monthly expenditure on food was US\$186 in the summer ( $\mathrm{n}$ $=17)$ and US\$228 in the winter $(\mathrm{n}=14)$. Accordingly, about 58 percent of monthly income was directed to the purchase of food items in both seasons. All 
households reported fishing practices and homegardening as food-generating activities (Figure 1). Extraction of plant resources (81 percent), agriculture (47 percent), and foraging of marine animals in the coastal zone (43 percent) were also noted as important sources of energy and nutrients. Hunting (33 percent) and livestock ( 28 percent) were less important.

At Araújo Island, the studied population comprised 162 individuals (83 females and 79 males) in 43 households. Their ages ranged from one month to 83 years old, with a median age between 14 and 51 years $(n=159)$. The average household was composed of four people, with the median between one and nine. Median monthly family income was US\$542 in the summer $(n=35)$ and US\$577 in the winter $(\mathrm{n}=34)$. Median expenditure on food was US\$346 in the summer ( $\mathrm{n}=$ $36)$ and US $\$ 287$ in the winter $(n=33)$. Around 64 percent and 50 percent of monthly income was spent on the purchase of foods in summer and winter, respectively. Similarly to Ponta Negra, fishing and homegardening were the predominant food-generating practices (Figure 1). Extraction of plant resources (60 percent) and foraging of marine animals on shore (53 percent) were also mentioned, and to a lesser extent livestock (25 percent), hunting (14 percent), and agriculture (11 percent).

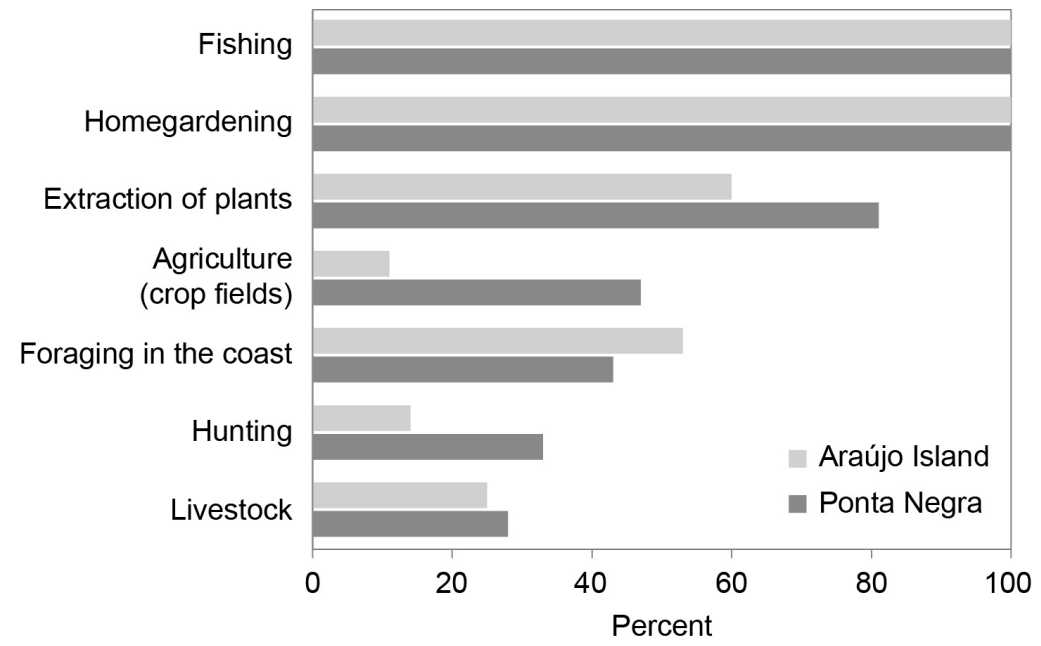

Figure 1. Activities related to local food production according to the households interviewed at Ponta Negra $(n=21)$ and Araújo Island ( $=43)$, Paraty, Brazil 


\section{Cultivated and harvested edible plants}

Altogether, 134 names of food plants cultivated and harvested were mentioned. Thirty of those were exclusive to Ponta Negra, while 27 were exclusive to Araújo Island. Seventy-seven were mentioned in both communities. Thus, the shared botanical knowledge on food plants corresponded to about half of all citations (57.5 percent).

The most-cited plants shared by both communities are listed in Table 2 and those exclusive to each community are listed in Table 3.

Table 2. Number of edible plants most cited at Ponta Negra and Araújo Island in Paraty, Brazil (percentage frequency of citations in parentheses)

\begin{tabular}{|c|c|c|c|c|c|c|}
\hline \multirow[b]{2}{*}{ Family } & \multirow[b]{2}{*}{ Scientific name } & \multirow[b]{2}{*}{$\begin{array}{l}\text { Local name } \\
\text { (English } \\
\text { name) }\end{array}$} & \multicolumn{2}{|c|}{ Ponta Negra } & \multicolumn{2}{|c|}{ Araújo Island } \\
\hline & & & Known & $\begin{array}{c}\text { Used in } \\
\text { the past } \\
\text { year }\end{array}$ & Known & $\begin{array}{c}\text { Used in } \\
\text { the past } \\
\text { year }\end{array}$ \\
\hline Apiaceae & $\begin{array}{l}\text { Eryngium foetidum } \\
\text { L. }\end{array}$ & $\begin{array}{l}\text { Coentro } \\
\text { (Coriander) }\end{array}$ & $18(85)$ & $18(85)$ & $29(67)$ & $27(62)$ \\
\hline Araceae & $\begin{array}{l}\text { Xanthosoma } \\
\text { sagittifolium (L.) } \\
\text { Schott }\end{array}$ & $\begin{array}{l}\text { Taioba } \\
\text { (Taro) }\end{array}$ & $8(38)$ & $8(38)$ & $20(46)$ & 16 (37) \\
\hline Arecaceae & Cocos nucifera L. & $\begin{array}{l}\text { Coco-da- } \\
\text { Bahia } \\
\text { (Coconut) }\end{array}$ & $9(42)$ & $8(38)$ & $28(65)$ & $25(58)$ \\
\hline Caricaceae & Carica papaya L. & $\begin{array}{l}\text { Mamão } \\
\text { (Papaya) }\end{array}$ & $8(38)$ & $8(38)$ & $22(51)$ & $18(41)$ \\
\hline Euphorbiaceae & $\begin{array}{l}\text { Manihot esculenta } \\
\text { Crantz }\end{array}$ & $\begin{array}{l}\text { Aipim } \\
\text { (Cassava) }\end{array}$ & $16(76)$ & $16(76)$ & $29(67)$ & $21(48)$ \\
\hline Lamiaceae & $\begin{array}{l}\text { Ocimum } \\
\text { americanum L. / } \\
\text { O. campechianum } \\
\text { Mill. }\end{array}$ & $\begin{array}{l}\text { Alfavaca } \\
\text { (Basil) }\end{array}$ & $10(47)$ & $10(47)$ & $24(55)$ & $22(51)$ \\
\hline Lamiaceae & $\begin{array}{l}\text { Ocimum basilicum } \\
\text { L. }\end{array}$ & $\begin{array}{l}\text { Manjericão } \\
\text { (Basil) }\end{array}$ & $14(66)$ & $13(61)$ & $21(48)$ & $18(41)$ \\
\hline Lauraceae & $\begin{array}{l}\text { Persea americana } \\
\text { Mill. }\end{array}$ & $\begin{array}{l}\text { Abacate } \\
\text { (Avocado) }\end{array}$ & $15(71)$ & $12(57)$ & $23(53)$ & 17 (39) \\
\hline Moraceae & $\begin{array}{l}\text { Artocarpus } \\
\text { heterophyllus Lam. }\end{array}$ & $\begin{array}{l}\text { Jaca } \\
\text { (Jackfruit) }\end{array}$ & $19(90)$ & $19(90)$ & $24(55)$ & 19 (44) \\
\hline Musaceae & $\begin{array}{l}\text { Musa Section } \\
\text { Musa }\end{array}$ & $\begin{array}{l}\text { Banana- } \\
\text { nanica } \\
\text { (Banana) }\end{array}$ & $13(61)$ & $13(61)$ & $22(51)$ & $20(46)$ \\
\hline Musaceae & $\begin{array}{l}\text { Musa Section } \\
\text { Musa }\end{array}$ & $\begin{array}{l}\text { Banana- } \\
\text { prata } \\
\text { (Banana) }\end{array}$ & $12(57)$ & $12(57)$ & 30 (69) & 30 (69) \\
\hline Myrtaceae & Psidium guajava L. & $\begin{array}{l}\text { Goiaba } \\
\text { (Guava) }\end{array}$ & $15(71)$ & $15(71)$ & 29 (67) & $26(60)$ \\
\hline
\end{tabular}




\begin{tabular}{|c|c|c|c|c|c|c|}
\hline \multirow[b]{2}{*}{ Family } & \multirow[b]{2}{*}{ Scientific name } & \multirow[b]{2}{*}{$\begin{array}{l}\text { Local name } \\
\text { (English } \\
\text { name) }\end{array}$} & \multicolumn{2}{|c|}{ Ponta Negra } & \multicolumn{2}{|c|}{ Araújo Island } \\
\hline & & & Known & $\begin{array}{c}\text { Used in } \\
\text { the past } \\
\text { year }\end{array}$ & Known & $\begin{array}{c}\text { Used in } \\
\text { the pas } \\
\text { year }\end{array}$ \\
\hline Passifloraceae & $\begin{array}{l}\text { Passiflora edulis } \\
\text { Sims. }\end{array}$ & $\begin{array}{l}\text { Maracujá } \\
\text { (Passion } \\
\text { fruit) }\end{array}$ & $9(42)$ & $9(42)$ & $24(55)$ & $23(53)$ \\
\hline Rutaceae & $\begin{array}{l}\text { Citrus reticulata } \\
\text { Blanco }\end{array}$ & $\begin{array}{l}\text { Laranja- } \\
\text { mexerica } \\
\text { (Mandarin) }\end{array}$ & $12(57)$ & $9(42)$ & $18(41)$ & $15(34)$ \\
\hline Rutaceae & $\begin{array}{l}\text { Citrus } x \text { limonia } \\
\text { (L.) Osbeck }\end{array}$ & $\begin{array}{l}\text { Limão- } \\
\text { cravo } \\
\text { (Lemon) }\end{array}$ & $16(76)$ & $15(71)$ & $30(69)$ & $29(67)$ \\
\hline
\end{tabular}

Other plants cited in both communities: Allium fistulosum L. (cebolinha); Anacardium occidentale L. (caju); Ananas comosus L. (Merr.) (abacaxi); Annona glabra L. /Rollinia mucosa (Jacq.) Baill. (condessa); Attalea humilis Mart. (coco-pindoba); Artocarpus altilis (Parkinson) Fosberg (fruta-pão); Averrhoa carambola L. (carambola); Bixa orellana L. (urucum); Brassica oleracea L. (couve); Bunchosia armeniaca (Cav.) DC. (cereja); Capsicum baccatum L. (pimenta-cumbari); Capsicum frutescens L. (pimenta-malagueta); Citrullus lanatus (Thunb.) Matsum. \& Nakai (melancia); Citrus aurantiifolia (Christm.) Swingle) (laranja-lima); Citrus aurantium L. (laranja-pocan); Citrus spl. (laranja-da-china); Citrus spp. (laranja); Coffea arabica L. (café); Colocasia esculenta (L.) Schott (inhame); Cucumis sativus L. (pepino); Cucurbita moschata Duchesne (abóbora-redonda); Cucurbita pepo L. (abóbora); Cucurbita spl. (abóbora-comprida); Cucurbita sp2. (abóbora-moranga); Dioscorea alata L. (cará); Eriobotrya japonica (Thunb.) Lindl. (ameixa-amarela); Eugenia cf. brasiliensis Lam. (grumixama); Eugenia uniflora L. (pitanga); Euterpe edulis Mart. (palmito); Inga cf. ingoides (Rich.) Willd.) (ingá); Ipomoea batatas (L.) Lam. (batata-doce); Lactuca sativa L. (alface); Laurus nobilis L. (louro); Malpighia emarginata DC. (acerola); Mangifera indica L. (manga); Manihot esculenta Crantz (mandioca); Morus nigra L. (amora); Musa Seccion Musa (banana-da-terra, banana-maçã, bananaouro, banana-preta and banana-São-Tomé); Musa spp. (banana); Myrciaria sp. (jabuticaba); Passiflora sp. (maracujá-do-mato); Petroselinum crispum (Mill.) Fuss (salsinha); Phaseolus vulgaris L. (feijão-preto); Plectranthus cf. amboinicus (Lour.) Spreng. (hortelã-de-galinha); Plinia edulis (Vell.) Sobral (cambucá); Psidium cattleianum Sabine (araçá); Saccharum officinarum L. (cana, cana-caiana, cana-preta and canasapo); Sechium edule (Jacq.) Sw. (chuchu); Solanum lycopersicum L. (tomate); Solanum tuberosum L. (batatabranca); Syzygium jambos Duthie (jambo-branco); Syzygium malaccense (L.) Merr. \& L.M. Perry (jambovermelho); Theobroma cacao L. (cacau); undetermined (melão) and Zea mays L. (milho).

Table 3. Edible plants mentioned in only one of the communities-Ponta Negra or Araújo Island, Paraty, Brazil

\begin{tabular}{|c|c|c|c|}
\hline \multicolumn{2}{|l|}{ Ponta Negra } & \multicolumn{2}{|l|}{ Araújo Island } \\
\hline Scientific name & Local name & Scientific name & Local name \\
\hline cf. Abuta sp. & Abuta & $\begin{array}{l}\text { Abelmoschus esculentus (L.) } \\
\text { Moench }\end{array}$ & Quiabo \\
\hline $\begin{array}{l}\text { Astrocaryum aculeatissimum } \\
\text { (Schott) Burret }\end{array}$ & Coco-preto & Allium cepa $\mathrm{L}$. & Cebola \\
\hline $\begin{array}{l}\text { cf. Attalea dubia (Mart.) } \\
\text { Burret }\end{array}$ & Coco-indaiá & Annona muricata L. & Graviola \\
\hline cf. Bactris vulgaris Barb. Rodr. & Coco-natal & Capsicum annuum L. & Pimentão \\
\hline $\begin{array}{l}\text { cf. Syagrus pseudococos } \\
\text { (Raddi) Glassman }\end{array}$ & Coco-pati & Capsicum baccatum L. & $\begin{array}{l}\text { Pimenta-de- } \\
\text { cheiro }\end{array}$ \\
\hline Brassica oleracea L. & Repolho & Capsicum chinense Jaqc. & $\begin{array}{l}\text { Pimenta- } \\
\text { vermelha }\end{array}$ \\
\hline
\end{tabular}


Use of Cultivated and Harvested Edible Plants by Caiçaras

\begin{tabular}{|c|c|c|c|}
\hline \multicolumn{2}{|l|}{ Ponta Negra } & \multicolumn{2}{|l|}{ Araújo Island } \\
\hline Scientific name & Local name & Scientific name & Local name \\
\hline Cajanus cajan (L.) Huth & $\begin{array}{l}\text { Feijão- } \\
\text { guandu }\end{array}$ & Capsicum sp. & $\begin{array}{l}\text { Pimenta- } \\
\text { pomaria }\end{array}$ \\
\hline Chorisia cf. speciosa A. St-Hil. & Paina & $\begin{array}{l}\text { Citrus latifolia (Tanaka ex Yu. } \\
\text { Tanaka) Tanaka }\end{array}$ & $\begin{array}{l}\text { Limão- } \\
\text { legítimo }\end{array}$ \\
\hline Cordia superba Cham. & Baba-de-boi & Citrus sp2 & $\begin{array}{l}\text { Laranja-da- } \\
\text { terra }\end{array}$ \\
\hline Coriandrum sativum L. & $\begin{array}{l}\text { Coentro- } \\
\text { salsa }\end{array}$ & Daucus carota L. & Cenoura \\
\hline $\begin{array}{l}\text { Cymbopogon citratus (DC.) } \\
\text { Stapf }\end{array}$ & Erva-cidreira & Mentha sp. & Hortelã \\
\hline Dioscorea sp1 & Cará-branco & Miconia albicans (Sw.) Steud. & Pixirica 1 \\
\hline Dioscorea sp2 & Cará-coco & Miconia prasina (Sw.) DC. & Pixirica 2 \\
\hline Dioscorea sp3 & Cará-roxo & Musa sp11 & $\begin{array}{l}\text { Banana- } \\
\text { São-José }\end{array}$ \\
\hline Eruca sativa Mill. & Rúcula & Non identified 4 & Agrião \\
\hline $\begin{array}{l}\text { Garcinia gardneriana (Planch. } \\
\text { \& Triana) Zappi }\end{array}$ & Bacupari & Non identified 5 & Orvalho \\
\hline Musa sp1 & $\begin{array}{l}\text { Banana- } \\
\text { cravo }\end{array}$ & $\begin{array}{l}\text { Pouteria caimito (Ruiz \& Pav.) } \\
\text { Radlk. }\end{array}$ & Abiu \\
\hline Musa sp5 & $\begin{array}{l}\text { Banana- } \\
\text { nanicona }\end{array}$ & Saccharum sp1 & $\begin{array}{l}\text { Cana- } \\
\text { amarela }\end{array}$ \\
\hline Musa sp8 & $\begin{array}{l}\text { Banana- } \\
\text { prata-veaca }\end{array}$ & Saccharum sp4 & Cana-cinza \\
\hline Musa sp10 & $\begin{array}{l}\text { Banana- } \\
\text { sacriviaca }\end{array}$ & Saccharum sp5 & $\begin{array}{l}\text { Cana- } \\
\text { listrada }\end{array}$ \\
\hline Non identified 1 & $\begin{array}{l}\text { Maminha- } \\
\text { de-sapo }\end{array}$ & Saccharum sp6 & Cana-paca \\
\hline Non identified 2 & Mandacaru & Saccharum sp8 & Cana-rosa \\
\hline Non identified 3 & $\begin{array}{l}\text { Maria- } \\
\text { peidorreira }\end{array}$ & Saccharum sp9 & Cana-roxa \\
\hline $\begin{array}{l}\text { Pausandra morisiana (Casar.) } \\
\text { Radlk. }\end{array}$ & Baquá & Solanum gilo Raddi & Jiló \\
\hline Phaseolus cf. lanatus Benth. & $\begin{array}{l}\text { Feijão- } \\
\text { magalô }\end{array}$ & $\begin{array}{l}\text { Syagrus romanzoffiana } \\
\text { (Cham.) Glassman }\end{array}$ & Coquinho \\
\hline Psidium guineense Sw. & $\begin{array}{l}\text { Araçá- } \\
\text { goiaba }\end{array}$ & Vigna sp. & $\begin{array}{l}\text { Feijão-de- } \\
\text { corda }\end{array}$ \\
\hline Saccharum sp2 & $\begin{array}{l}\text { Cana-sete- } \\
\text { metros }\end{array}$ & Zingiber officinale Roscoe & Gengibre \\
\hline Solanum melongena L. & Berinjela & & \\
\hline Spondias purpurea L. & Ciriguela & & \\
\hline $\begin{array}{l}\text { Virola bicuhyba (Schott ex } \\
\text { Spreng.) Warb }\end{array}$ & Bacubixaba & & \\
\hline
\end{tabular}


Regarding the plants cited in only one community (Table 3), we noticed that there were several species from the forest in Ponta Negra, such as the palms coco-indaiá (cf. Attalea dubia), coco-natal (cf. Bactris vulgaris), coco-pati (cf. Syagrus pseudococos) and coco-preto (Astrocaryum aculeatissimum). In Araújo Island, plants used for flavorings, such as mint (Mentha sp.), ginger (Zingiber officinale), chili pepper (Capsicum baccatum), cayenne pepper (Capsicum sp.) and red pepper (Capsicum chinense), were more prominent.

Homegardens were the main habitats where food plants were obtained (Figure 2), and were cited by 51 percent of Ponta Negra households and 65 percent in Araújo Island. Agricuture was an important source of food plants for Ponta Negra households, but not for those in Araújo Island. Neighbors provided 13 percent of food plants for households in Araújo Island, but were less important in Ponta Negra. Comparing Figures 1 and 2 we noticed that extractive activity was overestimated by the respondents when asked about this practice without detailing its frequency.

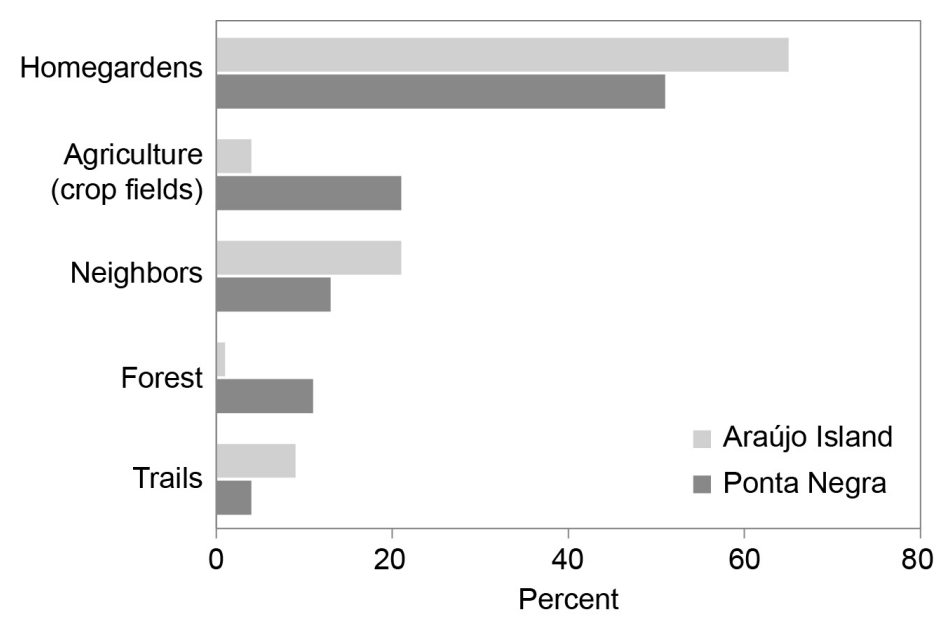

Figure 2. Cultivation and harvesting places for edible plants at Ponta Negra ( $n=21$ households) and Araújo Island ( $=43$ households), Paraty, Brazil

Note: Trails correspond to the paths that connect homes. Acquisition of food plants from neighbors refers to plants located in their crop fields and homegardens.

Food items consumed in households resulted in 486 citations in Ponta Negra and 1,195 citations in Araújo Island, using the 24-hour recall methodology. In 82 percent of Ponta Negra reports, foods were purchased and the rest were locally obtained (both animals and plants). In Araújo Island, the percentage of purchased items was similar (88 percent). The contribution of local food plants in the Caiçara diet was approximately 12 percent of the total citations in Ponta Negra and 8 percent in Araújo Island, and corresponded mainly to fruits and spices (Figure 3). 


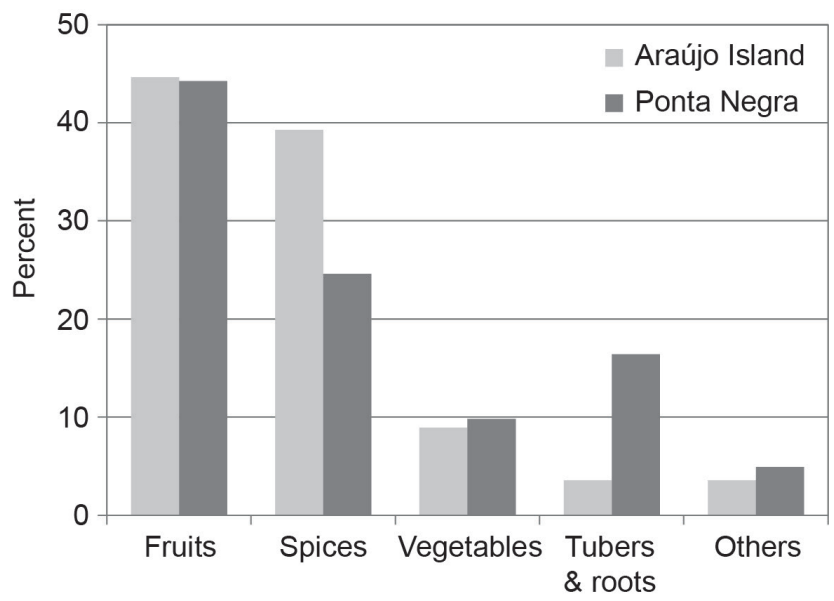

Figure 3. Parts of local edible plants consumed by households interviewed in Ponta Negra ( $n=21$ households) and Araújo Island ( $=43$ households), Paraty, Brazil

\section{Contrasts between seasons}

There were no significant differences in households' diets between summer and winter, taking into account food eaten in the 24 hours before interview and items present in households' food storage (Table 4). For Ponta Negra there were no differences between seasons for purchased food items $\left(X^{2}=0.243 ; p=0.666\right.$; $\mathrm{df}=1)$, local items of animal origin $\left(X^{2}=0.762 ; \mathrm{p}=0.5606 ; \mathrm{df}=1\right)$, and local items of plant origin $\left(X^{2}=3.086 ; p=0.1184 ; \mathrm{df}=1\right)$. For Araújo Island there was a marginal difference for local food of animal origin $\left(X^{2}=3.429 ; p=0.0956\right.$; $\mathrm{df}=1)$, but not for purchased food $\left(\mathrm{X}^{2}=0.953 ; \mathrm{p}=0.3471 ; \mathrm{df}=1\right)$, and local food of plant origin $\left(X^{2}=1.8 ; p=0.2272 ; \mathrm{df}=1\right)$.

Table 4. Food citations of households interviewed in Ponta Negra ( $n=16$ ) and Araújo Island ( $n=40$ ), Paraty, Brazil (considering the 24-hour recall and food storage analysis during summer and winter)

\begin{tabular}{lcccc}
\hline & \multicolumn{2}{c}{ Ponta Negra } & \multicolumn{2}{c}{ Araújo Island } \\
& Summer & Winter & Summer & Winter \\
\hline Purchased food & 254 & 271 & 792 & 738 \\
Local food (animals) & 15 & 8 & 40 & 19 \\
Local food (plants) & 36 & 17 & 66 & 46 \\
\hline
\end{tabular}

Although there were no significant differences, during winter the income in Ponta Negra is higher, and the amount of money spent on food and the proportion of purchased items is also higher. In Araújo Island, income hardly differed 
between the seasons and expenses for food and the record of items purchased were both highest in the summer. This indicates only slight differences in the households' economic behavior between summer and winter.

For both animal and plant foods of local origin there was a reduction in the number of citations in winter. Grouping different food resources in the analysis (e.g., fruits, roots, and tubers) may have been the reason why changes were not significant. Field notes and informal conversations with residents of both communities indicate a higher consumption of fruits in summer, and of roots and tubers during winter.

\section{Discussion}

The livelihoods of Caiçara populations in Ponta Negra and Araújo Island are marked by complementarity between activities that generate food and monetary resources. Studied households show some dependence on natural resources for their subsistence, as well as the importance of income-generating activities. Some authors (see Hesselberg \& Yaro, 2006; Pollock, 1975) recommend the most appropriate strategy to minimize human vulnerabilities to food insecurity is to combine activities that generate income and food resources. Pollock (1975) examined strategies for food acquisition on the Marshall Islands, Pacific Ocean, which had been under environmental, political, and economic pressures, and concluded that the purchase of food coupled with its acquisition directly from the environment provided the best combination to ensure adequate nutrition. In a study in rural Ghana, Hesselberg \& Yaro (2006) also concluded that the diversification of subsistence activities made contributions to local food security.

Hanazaki et al. (2013) evaluated the diversity of subsistence activities in 350 households within seven Caiçara communities in the municipality of Paraty, including Ponta Negra and Araújo Island, and found that the greater the diversification of activities, the greater the flexibility the families had in dealing with economic and environmental crises. This consequently improved the chances of creating a framework for food security. Depending on the kinds of activities performed by households, communities could be generalists or specialists, the latter being more susceptible to food insecurity. Ponta Negra was considered a generalist community by presenting a diverse range of subsistence activities (mainly food-generating practices), while Araújo Island was classified as a specialist community, with a concentration of paid activities focused on fishing (Hanazaki et al., 2013). However, it appears that food security, in terms of access to store-bought food, poses advantages for the Araújo Island community. Percentages of self-employment and salaried jobs, as well as government aid, were similar between Ponta Negra and Araújo Island. Nevertheless, the monthly income generated in Araújo Island was higher than in Ponta Negra. Greater 
chances of employment and better-paying jobs for Araújo Island residents are possibly related to easier access to the urban center of Paraty. In two Caiçara communities in the southern coast of São Paulo, the monthly income was higher where there were more paid job opportunities (Hanazaki et al., 2007).

Despite financial advantages of one community over the other, in general, there are economic difficulties in both locations. Considering that a food basket (consisting of food with a calculated daily energy requirement of 1,200 kilocalories per person) in the state of Rio de Janeiro between February and July 2011 cost about US\$133 per month (DIEESE, 2012), the income of the studied families (consisting of about four members) is not conducive to food security. Additionally, about a quarter of the family income comes from government support. This further emphasizes the importance of using natural resources.

With respect to unpaid work, Ponta Negra households showed a closer relationship with the use of flora and fauna than in Araújo Island, probably due to a greater degree of geographic isolation. Reyes-García et al. (2005) showed that human groups inhabiting remote areas, as opposed to urban centers, are more dependent on natural resources. If food security is understood in terms of diversification of unpaid work and thus local access to food resources, the families of Ponta Negra, at first glance, are in a better situation than the families of Araújo Island. However, a more realistic picture of local food security should jointly consider information on the role of subsistence activities, both paid and unpaid. From this point of view, both communities have advantages and disadvantages. In the case of Ponta Negra, since monetary resources were scarcer, the use of biodiversity resources gains an even more important role in minimizing vulnerability to food insecurity.

Another important aspect related to food access refers to social relations among neighbors and relatives. In some cases, households rely on their neighbors and relatives to obtain food plants. Cavechia et al. (2014) mapped social networks related to the donation and purchase of bitter and sweet manioc varieties among small farmers from Paraty and Imbituba (south Brazil), showing exchange practices between farmers within the community and with neighboring communities, and concluded that these social networks also contribute to the conservation of agrobiodiversity. Similarly, it can be said that the social relationships and networks occurring in Ponta Negra and Araújo Island benefit their food safety.

Food security or vulnerability are expected to affect the members of a given community in different ways (Dufour \& Teufel, 1995). For example, Hesselberg \& Yaro (2006) identified intrapopulation variations in rural populations in northern Ghana and categorized families by the degree of vulnerability to food insecurity using criteria such as per capita income and the number of meals 
during periods of food scarcity. In the studied Caiçara communities, there was intrapopulation variation on the socioeconomic profile of households in both sites, implying that food security is not reflected equally in all households visited.

Factors such as easy access to urban centers (Reyes-García et al., 2005), modernization (Furusawa, 2009), migration of human populations (Nguyen, 2003), and availability of natural resources (Ladio \& Lozada, 2004) influence local botanical knowledge. The proportion of edible plants known in Ponta Negra (both in absolute numbers and as a function of the number of interviews) was higher than that in Araújo Island, a result that can be related to the fact that Ponta Negra has a greater availability of natural environmental resources.

Borges and Peixoto (2009) conducted an ethnobotanical survey in a community near Ponta Negra, also located within the Juatinga Ecological Reserve, and found that 56.4 percent of the total citations of known plants were from the forest. According to Pimentel et al. (1997), forests are an important source of food and income generation for humans who live within or near these areas. The consumption of wild plants contributes to the diversification of diet, since species rarely marketed are incorporated into the menu of local people and can make valuable nutritional contributions (Della et al., 2006; Kinupp \& Barros, 2010). Citation frequency for wild plants was lower on Araújo Island, and was found to be mainly in anthropic areas such as trails and homegardens.

Additionally, family farming is disappearing with greater intensity on Araújo Island, and some research has indicated that this practice is gradually disappearing in Caiçara livelihoods at large (Adams, 2000; Borges \& Peixoto, 2009; Hanazaki et al., 2007). Crop field plants reported in Ponta Negra and Araújo Island, such as manioc varieties, have been mentioned in other studies as important caloric sources (Borges \& Peixoto, 2009; Hanazaki et al., 2007, 2000; Miranda \& Hanazaki, 2008; Peroni et al., 2008; Rossato et al., 1999). Other plants cultivated in crop fields that are also important sources of carbohydrates for families at Ponta Negra and Araújo Island were sweet potato, taro, yam, and potato varieties. Furthermore, these roots and tubers have the advantage of being stored in the soil for long periods of time and consumed in situations of economic difficulties.

Homegardens play an important role in providing plant foods. These habitats are widely recognized as havens for the conservation of biological diversity, as well as food stocks especially important in times of food insecurity (Buchmann, 2009; Valadão et al., 2006). Homegardens are very versatile and can even persist under urbanization processes (Gandolfo et al., 2010). Given the changes in livelihoods of the Caiçaras, homegardens seem to be the areas of food production more suited to this new reality. In Araújo Island, the importance of homegardens 
seems to be greater than in Ponta Negra, since plant extraction and agriculture no longer contribute as much to the local livelihoods. Overall, the richness found in Caiçara homegardens and in other regions of Brazil (see Gandolfo et al., 2010; Valadão et al., 2006) is characterized by the presence of fruit trees, vegetables, and seasonings, such as oranges, lemons, guava, passion fruit, avocado, papaya, chayote, squash, basil, and peppers. Homegardens at Araújo Island had higher numbers for spice citations than Ponta Negra, perhaps due to smaller gardens, where growing small plants is a priority or the only possibility.

Changes in the ways of obtaining food items have implications for Caiçara consumption patterns (MacCord \& Begossi, 2006). Results regarding the food intake of families in Ponta Negra and Araújo Island show that diet depends in large part on income-generating activities, since most items consumed were purchased. In the Amazon, Silva \& Begossi (2009) considered that in the past 30 years the decline of traditional subsistence activities and the expansion of urban areas were important changes affecting local diets. They compared the diet between urban and rural areas and found that the consumption of purchased food was higher in urban (65) than in rural areas (31), showing that where there is greater diversity of practices aimed at plant extraction and domestic food production, a higher proportion of natural resources are incorporated in the diet (Silva \& Begossi, 2009).

The most-consumed local plants by Caiçara households were fruits. According to the Brazilian food pyramid proposed by Philippi et al. (1999), in a daily diet intake of 1,600 kilocalories the proportion of fruit should be 15.7 percent of the total food consumed. Apparently only a small fraction of the Caiçara diet consisted of locally obtained fruits. However, these results may have been underestimated by the limitations of the 24-hour recall approach. Recording wild and cultivated fruits by this method is complex, influenced by the forgetfulness of informants, fruiting period, preferences, and taboos (Dufour \& Teufel, 1995; Hanazaki \& Begossi, 2003).

Finally, critical periods of food insecurity were not identified in this research. As noted by Hanazaki and Begossi (2000) in a Caiçara community in São Paulo, as tourism activities increased during summer, monthly income also increased. Additionally, intensification of fishing activities tends to increase the income for fishermen's families. On this basis, it was expected that the monthly income of families in Ponta Negra and Araújo Island would be higher in summer and lower in winter. However, changes were minimal, leading to the conclusion that variations in food intake at Ponta Negra and Araújo Island between the two seasons seem to be related to the availability of certain environmental resources and not to economic fluctuations. 
The results of this study contribute to deepen the discussions related to food security and dependence of food resources locally obtained, especially in rural communities facing changes in their livelihoods. Acquisition and consumption of local edible plants by Caiçara families studied is a way to reduce vulnerability to food insecurity. Without the possibility of harvesting and growing plants, food security of the Caiçara would be related to the purchase of food items, and our research shows that it would not be possible for these communities to obtain an adequate diet based only on self-employment, paid jobs, and government aid. Also, the effects of seasonality in the production of local food items may become confounded with seasonal effects on income from sources such as tourism and other livelihood activities less related to natural resources. Furthermore, foodgenerating activities enhance food sovereignty, and contribute to biodiversity conservation and the maintenance of cultural aspects of Caiçara livelihoods.

\section{Acknowledgments}

We thank the participants in the study for their responses and for making this research possible. Thanks to N. P. Lunelli, L. A. Cavechia, and A. L. A. A. Assis for helping during fieldwork; to those who assisted in plant identification (A. B. Junqueira, C. P. Simionato, J. F. A. Baumgratz, L. Z. O. Campos, M. L. Del Rei Souza, M. O. O. Cano, N. Peroni, R. C. Martins, R. M. Begnini, and R. L. Barbieri); to $\mathrm{CNPq}$ for masters scholarship granted to $\mathrm{M}$. Giraldi and research productivity grant awarded to N. Hanazaki; to the UFRPE Graduate Program in Botany for helping with fieldwork costs; to the International Development Research Center for the funding of the Community-Based Resource Management and Food Security in Coastal Brazil project; and to the Applied Ethnobotany Laboratory (UFRPE) and the Human Ecology and Ethnobotany Laboratory (UFSC) for institutional support. This paper is contribution number 14 supported by CAPES/PNADB through the project Knowledge, Use and Conservation of Plant Biodiversity in Atlantic Forest and Caatinga (UFSC/UFRPE/UFRGS).

\section{References}

Adams, C. (2000). Caiçaras na Mata Atlântica: Pesquisa cientifica versus planejamento e gestão ambiental. São Paulo: FAPESP.

Albuquerque, U. P., Lucena, R. F. P., \& Alencar, N. L. (2010). Métodos e técnicas para coleta de dados etnobiológicos. In U. P. Albuquerque, R. F. P. Lucena, \& L. V. Cunha (Orgs.), Métodos e técnicas na pesquisa etnobiológica e etnoecológica (2nd ed.). Recife: COMUNIGRAF. 
Albuquerque, U. P., Lucena, R. F. P., \& Neto, E. M. (2010). Seleção dos participantes da pesquisa. In U. P. Albuquerque, R. F. P. Lucena, \& L. V. Cunha (Orgs.), Métodos e técnicas na pesquisa etnobiológica e etnoecológica (2nd ed.). Recife: COMUNIGRAF.

Albuquerque, U. P., Medeiros, P. M., \& Almeida, A. L. S. (2010). Noções de estatística inferencial aplicada à etnobiologia e etnoecologia. In U. P. Albuquerque, R. F. P. Lucena, \& L. V. Cunha (Orgs.), Métodos e técnicas na pesquisa etnobiológica e etnoecológica (2nd ed.). Recife: COMUNIGRAF.

Ayres, M., Ayres, M., Jr., Ayres, D. L., \& Santos, A. A. S. (2007). BioEstat 5.0: Aplicações estatísticas nas áreas das ciências biológicas e médicas. Belém: Sociedade Civil Mamirauá.

Barbetta, P. A. (2002). Estatística aplicada às ciências sociais. Florianópolis: UFSC.

Borges, R., \& Peixoto, A. (2009). Conhecimento e uso de plantas em uma comunidade Caiçara do litoral sul do estado do Rio de Janeiro, Brasil. Acta Botanica Brasilica, 23(3), 769-779.

Brasil. (2002). Ministério da Saúde. Conselho Nacional de Saúde. Comissão Nacional de Ética em Pesquisa. Manual operacional para comitês de ética em pesquisa (1st ed.). Brasília: Ministério da Saúde.

Buchmann, C. (2009). Cuban home gardens and their role in social-ecological resilience. Human Ecology, 37, 705-721.

Cavechia, L. A., Cantor, M., Begossi, A., \& Peroni, N. (2014). Resource usepatterns in swidden farming communities: Implications for the resilience of cassava diversity. Human Ecology, 42, 605-616.

CONSEA (Construção do Sistema e da Política Nacional de Segurança Alimentar e Nutricional: A experiência brasileira). (2009). Retrieved from https://www. fao.org.br/download/Seguranca_Alimentar_Portugues.pdf

Della, A., Paraskeva-Hadjichambi, D., \& Ch Hadjichambis, A. (2006). An ethnobotanical survey of wild edible plants of Paphos and Lanarca countryside of Cyprus. Journal of Ethnobiology and Ethnomedicine, 2(34), 1-9.

DFID (Department for International Development). (1999). Sustainable livelihoods guidance sheets. London: DFID.

DIEESE (Departamento Intersindical de Estatística e Estudos Sócio-Econômicos). (2012). Retrieved from http://turandot.dieese.org.br/bdcesta/cesta.html

Diegues, A. C. (2002). Aspectos sociais e culturais do uso dos recursos florestais da Mata Atlântica. In L. L. Simões \& C. F. Lino (Orgs.),Sustentável Mata Atlântica: A exploração de seus recursos florestais. São Paulo: Senac.

Dufour, D. L., \& Teufel, N. I. (1995). Minimum data sets for the description of diet and measurement of food intake and nutritional status. In E. F. Moran (Ed.), The comparative analysis of human societies. Boulder: Lynne Rienner. 
FAO (Organização das Nações Unidades para Agricultura e Alimentação). (2009). How to feed the world in 2050. Retrieved from http://www.fao.org/fileadmin/ templates/wsfs/docs/expert_paper/How_to_Feed_the_World_in_2050.pdf

Furusawa, T. (2009). Changing ethnobotanical knowledge of the Roviana people, Solomon Islands: Quantitative approaches to its correlation with modernization. Human Ecology, 37, 147-159.

Gandolfo, E. S., Ribeiro, T. M., \& Hanazaki, N. (2010). Can the homegardens persist with the urbanization of the coastline? In M. L. Pochenttino, A. H. Ladio, \& P. M. Arenas (Eds.),Tradiciones \& transformaciones en etnobotánica. San Salvador de Jujuy: CYTED - Programa Iberoamericano Ciencia y Tecnología para el Desarrollo.

Hanazaki, N., \& Begossi, A. (2000). Fishing and niche dimension for food consumption of Caiçaras from Ponta do Almada (Brazil). Human Ecology Review, 7(2), 52-62.

Hanazaki, N., \& Begossi, A. (2003). Does fish still matter? Changes in the diet of two Brazilian fishing communities. Ecology of Food and Nutrition, 42, 279-301.

Hanazaki, N., Alves, R. R. N., \& Begossi, A. (2009). Hunting and use of terrestrial fauna used by Caiçaras from the Atlantic Forest coast (Brazil). Journal of Ethnobiology and Ethnomedicine, 5, 36. Retrieved from http://www.ethnobiomed.com/content/5/1/36

Hanazaki, N., Berkes, F., Seixas, C. S., \& Peroni, N. (2013). Livelihood diversity, food security and resilience among the Caiçara of coastal Brazil. Human Ecology, 41(1), 153-164.

Hanazaki, N., Castro, F., Oliveira, V. G., \& Peroni, N. (2007). Between the sea and the land: The livelihood of estuarine people in southeastern Brazil. Ambiente \& Sociedade, 10(1), 1-16.

Hanazaki, N., Tamashiro, J. Y., Leitão-Filho, H. F., \& Begossi, A. (2000). Diversity of plant uses in two Caiçara communities from the Atlantic Forest coast, Brazil. Biodiversity and Conservation, 9, 597-615.

Hesselberg, J., \& Yaro, J. A. (2006). An assessment of the extent and causes of food insecurity in northern Ghana using a livelihood vulnerability framework. GeoJournal, 67, 41-55.

IBGE (Instituto Brasileiro de Geografia e Estatística). (2010). Pesquisa nacional por amostra de domicílios segurança alimentar 2004/2009. Rio de Janeiro: IBGE. Retrieved from http://www.ibge.gov.br/home/estatistica/populacao/ seguranca_alimentar_2004_2009/pnadalimentar.pdf

IBGE (Instituto Brasileiro de Geografia e Estatística). (2011). Retrieved from http://cidades.ibge.gov.br

Kinupp, V. F., \& Barros, I. B. I. (2010). Agrobiodiversidade nativa, uma riqueza negligenciada: Diversidade de plantas alimentícias não-convencionais (PANCs) 
na região metropolitana de Porto Alegre. In L. C. Ming, M. C. Amorozo, \& C. W. Kffuri (Orgs.), Agrobiodiversidade no Brasil: Experiências e caminhos da pesquisa. Recife: NUPEEA.

Kovach, W. L. (2005). MVSP - a multivariate statistical package for Windows, version 3.1. Wales: Kovach Computing Services.

Ladio, A. H., \& Lozada, M. (2004). Patterns of use and knowledge of wild edible plants in distinct ecological environments: A case study of a Mapuche community from northwestern Patagonia. Biodiversity and Conservation, 13, 1153-1173.

Lorenzi, H. (2010). Flora brasileira: Arecaceae (palmeiras) (1st ed.).

Nova Odessa: Plantarum.

Lorenzi, H., Bacher, L., Lacerda, M., \& Sartori, S. (2006). Frutas brasileiras e exóticas cultivadas de consumo in natura (1st ed.). Nova Odessa: Plantarum.

Lorenzi, H., \& Souza, V. C. (2008). Botânica Sistemática: Guia ilustrado para identificação das famílias de Fanerógamas nativas e exóticas no Brasil, baseado em APG II (2nd ed.). Nova Odessa: Plantarum.

MacCord, P. L., \& Begossi, A. (2006). Dietary changes over time in a Caiçara community from the Brazilian Atlantic Forest. Ecology and Society, 11(2), 38.

Mahdi, Shivakoti, G. P., \& Schmidt-Vogt, D. (2009). Livelihood change and livelihood sustainability in the uplands of Lembang subwatershed, west Sumatra, Indonesia, in a changing natural resource management context. Environmental Management, 43, 84-99.

Maxwell, S., \& Smith, M. (1992). Household food security: A conceptual review. In S. Maxwell \& R. T. Frankenberger (Eds.),Household food security: Concepts, indicators, measurements. A technical review. New York and Rome: UNICEF and IFAD.

MDG (Millenium Development Goals). (2010). Retrieved from http://www. un.org/millenniumgoals/

Miranda, T. M., \& Hanazaki, N. (2008). Conhecimento e uso de recursos vegetais de restinga por duas comunidades das ilhas do Cardoso (SP) e de Santa Catarina (SC), Brasil. Acta Botanica Brasilica, 22(1), 203-215.

Mosaico Bocaina. (2011). Retrieved from http://www.bocaina.org.br/mosaicobocaina/menu-interno-ucs

Mourão, J. S., \& Montenegro, S. C. S. (2006). Pescadores e peixes: O conhecimento e o uso da taxonomia folk baseada no modelo berliniano. Recife: Ed. Livro Rápido.

Murrieta, R. S. S., Dufour, D. L., \& Siqueira, A. D. (1999). Food consumption and subsistence in three Caboclo populations on Marajo Island, Amazonia, Brazil. Human Ecology, 27(3), 455-475. 
Nguyen, M. L. T. (2003). Comparision of food plant knowledge between urban Vietnamese living in Vietnam and in Hawai'i. Economic Botany, 57(4), 472-480.

ONU (Conferência das Nações Unidas para o Desenvolvimento Sustentável). (2012). Retrieved from http://www.onu.org.br/rio20/

Peroni, N., Araújo, H. F. P., \& Hanazaki, N. (2010). Métodos ecológicos na investigação etnobotânica e etnobiológica: $\mathrm{O}$ uso de medidas de diversidade e estimadores de riqueza. In U. P. Albuquerque, R. F. P. Lucena, \& L. V. Cunha (Orgs.), Métodos e técnicas na pesquisa etnobiológica e etnoecológica (2nd ed.). Recife: COMUNIGRAF.

Peroni, N., Begossi, A., \& Hanazaki, N. (2008). Artisanal fishers' ethnobotany: From plant diversity use to agrobiodiversity management. Environment Development and Sustainability, 10, 623-637.

Philippi, S. T., Latterza, A. R., Cruz, A. T. R., \& Ribeiro, L. C. (1999). Pirâmide alimentar adaptada: Guia para escolha dos alimentos. Revista de Nutrição, 12(1), 65-80.

Pimentel, D., McNair, M., Buck, L., Pimentel, M., \& Kamil, J. (1997). The value of forests to world food security. Human Ecology, 25(1), 91-120.

Pollock, N. J. (1975). The risks of dietary change: A Pacific atoll example. In M. L. Arnott (Ed.), Gastronomy: The anthropology of food and food habits. Paris: Mouton Publishers.

Ramakrishnan, P. S. (2001). Increasing population and declining biological resources in the context of global change and globalization. Journal of Biosciences, 26(4), 465-479.

Reis, R. C. C. (2006). Palmeiras (Arecaceae) das restingas do estado do Rio de Janeiro, Brasil. Acta Botanica Brasilica, 20(3), 501-512.

Reyes-García, V., Valdez, V., Huanca, T., \& Wilkie, W. L. D. (2005). Knowledge and consumption of wild plants: A comparative study in two Tsimane' villages in the Bolivian Amazon. Ethnobothany Research \& Applications, 3, 201-207.

Ribeiro, M. C., Metzger, J. P., Martensen, A. C., Ponzoni, F. J., \& Hirota, M. M. (2009). The Brazilian Atlantic Forest: How much is left, and how is the remaining forest distributed? Implications for conservation. Biological Conservation, 142, 1141-1153.

Rossato, S. C., Leitão-Filho, H. F., \& Begossi, A. (1999). Ethnobotany of Caiçaras of the Atlantic Forest Coast (Brazil). Economic Botany, 53(4), 387-395.

Silva, A. L., \& Begossi, A. (2009). Biodiversity, food consumption and ecological niche dimension: A study case of the riverine populations from Rio Negro, Amazonia, Brasil. Environment Development and Sustainability, 11, 489-507. 
SOS Mata Atlântica. (2009). Retrieved from http://www.sosmatatlantica.org.br/ index.php

Valadão, L. M., Amorozo, M. C. M., \& Motta, D. G. (2006). Produção de alimentos na unidade domiciliar, dieta e estado nutricional: A contribuição dos quintais em um assentamento rural no estado de São Paulo. In U. P. Albuquerque \& C. F. Almeida (Orgs.), Tópicos em conservação e etnobotânica de plantas alimentícias. Recife: NUPEEA.

Valentin, J. L. (2000). Ecologia numérica. Uma introdução à análise multivariada de dados ecológicos. Rio de Janeiro: Interciência.

Vieira, S. (1991). Introdução à bioestatística. Rio de Janeiro: Campos. 
This text taken from Human Ecology Review Volume 20, Number 2, 2014, published 2014 by ANU Press, The Australian National University, Canberra, Australia. 